\title{
Examining green production and its role within the competitive strategy of manufacturers
}

\author{
Tim Baines ${ }^{1}$, Steve Brown ${ }^{2}$, Ornella Benedettini ${ }^{3}$, Peter Ball ${ }^{4}$ \\ ${ }^{1}$ Aston Business School, ${ }^{2}$ University of Exeter Business School, ${ }^{3}$ Institute for Manufacturing, University of \\ Cambridge, ${ }^{4}$ Cranfield University (UNITED KINGDOM) \\ t.baines@,aston.ac.uk; steve.brown@,exeter.ac.uk; ob256@,cam.ac.uk; p.d.ball@,cranfield.ac.uk,
}

Received September 2011

Accepted March 2012

\section{Abstract:}

Purpose: This paper reviews current literature and contributes a set of findings that capture the current state-of-the-art of the topic of green production.

Design/methodology/approach: A literature review to capture, classify and summarize the main body of knowledge on green production and, translate this into a form that is readily accessible to researchers and practitioners in the more mainstream operations management community.

Findings: The existing knowledge base is somewhat fragmented. This is a relatively unexplored topic within mainstream operations management research and one which could provide rich opportunities for further exploration.

Originality/value: This paper sets out to review current literature, from a more conventional production operations perspective, and contributes a set of findings that capture the current state-of-the-art of this topic.

Keywords: green, production, operations, competitive strategy 


\section{Introduction}

The term "green" is now widely used, although its origins lie more in the popular press than the scientific community. Increasingly, the term is used interchangeably on the more established "sustainability" concept, and so this means taking a holistic view of environmental, social and economic impact (Dobers \& Wolff, 2000; Kleindorfer, Singhal, \& van Wassenhove, 2005; Rahimifard \& Clegg, 2007; Saha \& Darnton, 2005; Seliger, Kim, Kernbaum \& Zettl, 2008). Elkington (1997, p. 22) presents the challenge to achieve sustainability as "an unprecedented source of commercial opportunity for competitive companies, through technological innovation and improved eco-efficiency".

The underpinning assumption is that financial success can be made consistent with an ethical, environment and society compliance (Dobers \& Wolff, 2000; Mohanty \& Deshmukh, 1998; Stead \& Stead, 2000). Accordingly, green manufacturers are those that make a commitment to a wide and long-term assessment of the impact of their activities and, thereby, to influence issues such as people's quality of life and well-being, protection and security, economic growth, social and economic justice (Hart, 1995; Saha \& Darnton, 2005). As presented later, we see green production is now commonly seen as "the application of environmentally and socially sensitive practices to reduce the negative impact of manufacturing activities while, at the same time, harmonising the pursuit of economic benefits".

Green production is rapidly growing in importance (Brandt, 2007; Corbett \& Klassen, 2006; Dills \& Stone, 2007; Stead \& Stead, 2000). As populations grow, and emerging economies expand, the planet's ecosystems and resources are experiencing tremendous challenges (de Burgos \& Cespedes, 2001; Esty \& Winston, 2009; Hart, 1995; Industry Today, 2010; Kleindorfer et al., 2005; Mohanty \& Deshmukh, 1998). Production systems, that supply the growing demand for goods, are linked to adverse environment impacts (Frosch \& Gallopoulos, 1989). For example, as countries such as China enjoy the benefits of lifestyles close to those of the western societies, the impact of human activities is estimated to rise ten-fold by 2050 (Lisney, Riley \& Banks, 2003).

Urgent measures are needed to be taken to achieve a pivotal change in the way society in general, and industry in particular, manages natural resources (Brandt, 2007; Lee, 2008; Lisney et al., 2003). As a consequence, many governments have formally embraced environmental policies and regulations, and the free market is placing a clear premium on those companies who are able to offer green credentials (Brandt, 2007; Miles \& Covin, 2000; Saha \& Darnton, 2005; Sarkis \& Cordeiro, 
2001; Yang, Lin, Chan \& Sheu, 2010). For "production" based companies, such green credentials can be achieved in a number of ways including the materials used within products, how products are produced, and the ease of dealing with a product at the end of its life.

Recent years have seen a rapid expansion in both the interest and body of literature on green production. In 2001, Dangayach and Deshmukh (2001) recognised the relatively infantile nature of environmental matters in the mainstream manufacturing and operations strategy research and argued for more studies in this area. Yet in October 2007, Rahimifard and Clegg (2007), in their editorial of the special issue on sustainable design and manufacture for the International Journal of Production Research, concluded that there is an urgent and imperative need for further research in every phase of a product's life-cycle. There is little to indicate that the challenges particular to production operations are any exception. This situation is succinctly captured by Kleindorfer et al. (2005) when they argue that we must enlarge our perspective in operations management to include "the planet" because companies will be expected to do so.

The more mainstream operations management community still lacks, however, a cohesive understanding of green production. While those within the sustainability community may be fully conversant with the interpretations, ideas, and methods associated with Green, this is not necessarily the case with those practitioners and researchers from more mainstream production operations management. This therefore is the motivation behind our research. This paper sets out to review current literature, from a more conventional production operations perspective, and contributes a set of findings that capture the current state-of-the-art of this topic. In particular, it examines the evolution of green terminology, categorises green production types, and the role that green production can take in the competitive strategy of a manufacturer. This paper is structured to first present the literature review methodology that has been used, along with the research questions that have initially been used to guide the identification and analysis of articles. The findings from this review are then presented, discussed and conclusions drawn.

\section{Research programme}

\subsection{Aim, scope and guiding research questions}

The general aim of this paper is to capture, classify and summarize the main body of literature on green production and, translate this into a form that is readily 
accessible to researchers and practitioners in the more mainstream operations management community.

Setting the scope for this study has itself been challenging. As mentioned earlier, the term "green" is currently in vogue with the popular media, and yet tends to lack a rigorous scientific basis. Many articles are given a "green-wash" to increase their appeal. To deal with this issue, this review has focused on those publications that attempt to make a substantive contribution to the field; in particular, those that submit to provide green definitions, concepts, cases and challenges. Similarly, a definition of production has also been necessary to scope this literature review, which we have generally referred to as a conversion process dealing with physical materials and discrete components. This paper deals exclusively with manufacturing, and outside our scope have been papers that deal with agriculture, construction, petrochemical, and mining. Also, we have focused at the level of the business, rather than national or international policy, and so articles dealing with such topics as climate change, government policy, renewable energies, eco-cities, and life-cycle analysis have been excluded in our paper unless they are directly relevant to this review.

To guide the literature review process it has been necessary to translate the aim into a series of research questions. Here, it is important to emphasise that these questions have been generated by the research team to initially seed the literature review process and elicit relevant knowledge (see Baines, Lightfoot, Williams \& Greenough, 2006; Benedettini, Baines, Lightfoot \& Greenough, 2009 for a further illustration of this process). These questions were used to generally guide the identification and screening of the literature, and consisted of:

- What is the meaning of "green" production, and how does it relate to the other associated terminology?

- How does green production differ from conventional ways of doing business, and what are the consequences?

- Where are the leading examples of green production practice?

- What are the motives and hurdles of adopting green production, and where are the challenges to address in the future of its development?

- How does green production relate to competitive strategy, and what roles may be taken? 


\subsection{Planning and execution of the review}

Even using the scoping process summaries above, there is an enormous volume of publications and publication sources pertaining to address green issues. This review has, therefore, centered on the Business Source Complete Database, which offers access to the most relevant scholarly, government, and general interest publications. It covers a wide range of sources including the Journal of Cleaner Production, Long Range Planning, Business Strategy and the Environment, the Journal of Environmental Management, Ecological Economics, Greener Management International, and the recently established International Journal of Sustainable Engineering. In addition, this database covers a leading collection of business publications, including those from the Harvard Business Review, the International Journal of Production Economics, the International Journal of Operations and Production Management, and the International Journal of Production Research.

A range of keywords were initially identified from the research questions, these included "green", "sustainable", "environmental" or "environmentally-" "clean" or "cleaner", "ecological" or "eco-efficient". The word "production" was combined as an additional keyword in order to ensure some direct relevance of the publications to the scope of the review. Several search strings were also identified by replacing the keyword "production" with just "manufacturing" or with the names of the functional areas that businesses can involve in their greening plans, like "operations", "marketing", "management", and "strategy". Finally, keywords were considered for some sector-specific interpretations of the green production view, namely "ethical", "organic" and "fair-trade". Initially, the search for publications was constrained to those published in the last ten years. Then, as the search matured and the typology of the literature in this field became more apparent, the review was naturally extended.

Using the initial search criteria and database some 2700 publications were identified. Duplicates were removed and each was assessed for relevance. Abstracts and contents were then considered in further depth and, through this process, the number of relevant publications reduced to 72 . Subjectivity of this process was reduced through a panel process including two independent researchers. The review was enhanced by cross-checking of references which increased the list to 110. These 110 papers formed the basis of this review paper. Finally, it should be noted that we have not attempted to reference every relevant article in this review; rather we have sought to emphasis those that appear most relevant to our 
purpose. Consequently, an in depth perusal of fewer, well selected publications was favoured rather than inclusion of a broad range of potentially relevant data sources.

\subsection{Results of the search process}

Cited a large number of times in the subsequent literature, Hart $(1995,1997)$ and Porter and van der Linde (1995) can be considered as seminal authors in the field. Large contributors have also been made by authors such as Azzone, Bertelè and Noci (1997); Azzone and Noci (1998a, 1998b), Kleindorfer et al. (2005) and Srivastava (2007). In general, authors publishing green production have been from the USA or the UK than other nations. However, a few relevant papers have also emerged from other European countries, especially Italy (Azzone \& Bertelè, 1994; Azzone et al., 1997; Azzone, Bianchi, Mauri \& Noci, 1997; Azzone \& Noci, 1998a, 1998b) and Germany (Seliger, Kim et al., 2008; Seuring, 2004). In addition, recent years have seen increasing contributions from Asian countries, including China (Hui, He \& Dang, 2002; Lu, Wu, \& Kuo, 2007), Taiwan (Chiang \& Tseng, 2005; Lee, 2008) and India (Sangwan, 2006; Srivastava, 2007).

Research on green production has originated a steady output of publications over time. These are disseminated across a large number of scientific as well as practitioner journals. Intriguingly, some of the most relevant articles discussing the principles, perspectives, and challenges of green production have appeared on general interest titles, such as the Harvard Business Review (Hart, 1997; Kleiner, 1991; Porter \& van der Linde, 1995; Reinhardt, 1999), the Academy of Management Review (Hart, 1995) or the International Journal of Operations and Production Management (de Burgos \& Cespedes, 2001). Technical papers focusing on tools and techniques for green production are predominant on sector specific journals, with a leading contribution of the Journal of Cleaner Production, Business Strategy and the Environment, and the Journal of Business Ethics.

Collectively, research on green production has covered a range of topics. About $22 \%$ of the reviewed papers discuss the green production view or provide alternative classifications of green production approaches. A further $10 \%$ of the authors focus on the drivers of environmental behaviour and investigate the factors that affect the green attitudes of production companies. Other relevant topics are related to green operations, with $36 \%$ of the reviewed papers falling in this area. Here, the papers discuss the impact of green production on the operations function $(8 \%)$ or focus on specific aspects of green operations, including cleaner technologies $(10 \%)$, environmental management systems (5\%), green supply and product chain management $(11 \%)$, and green marketing $(6 \%)$. Surprisingly, there 
are not many papers that explicitly address principles for green product design, the topic being dealt with in the more general domain of product stewardship practices. This is consistent with Srivastava (2007) who found the problem context for green operations to be much wider than the one for product innovation.

\section{Generation of key findings}

\subsection{A definition of green production}

The term "green" is used frequently in everyday life, and yet its definition tends to be ambiguous (Saha \& Darnton, 2005; Roarty, 1997; Kleiner, 1991; Elsayed, 2006). It is commonly associated with a wide range of issues, such as eco-friendly living, recycling, energy saving, waste management, pollution reduction, offsetting, etc. Intriguingly, there are relatively few formal definitions of green production given within the literature (see table 1 ). When considered in a production context, green is readily used as an umbrella term covering a range of concepts, such as "environmentally-conscious", "ethical", "organic" and "fair-trade" production. These concepts address specific forms of production, namely:

- Environmentally-conscious: Industrial companies make themselves committed with slowing down the degradation of the natural resources and the planet's ecosystems.

- Ethical: Business enterprises take responsibility for the rights of the workers in their supply chains according to specific labour standards or codes of practice (e.g. Ethical Trading Initiative code in the UK).

- Fair-trade: Buyers accept to pay prices above market levels for products of disadvantaged or marginalised producers, typically from the Third World, when these products are provided with the fair-trade label.

- Organic: Food manufacturers or producers of certain non-food items, such as health and beauty products or textiles, obtain a certification from an entitled organization, (e.g. in the UK, the Department for Environment, Food and Rural Affairs, the Organic Soil Association, the Organic Food Federation) meaning that their products are made from a balanced living soil. 


\begin{tabular}{|c|c|}
\hline Author & Definition \\
\hline $\begin{array}{l}\text { Melnyk and Smith } \\
\text { (1996) }\end{array}$ & $\begin{array}{l}\text { A system that integrates product and process design issues with issues of } \\
\text { manufacturing planning and control in such a manner as to identify, quantify, } \\
\text { assess, and manage the flow of environmental waste with the goal of reducing } \\
\text { and ultimately minimizing environmental impact while also trying to maximize } \\
\text { resource efficiency }\end{array}$ \\
\hline Shiino (1999) & The manufacturing aiming at the symbiosis with the global environment \\
\hline $\begin{array}{l}\text { Yang, Lu, Guo \& } \\
\text { Yamamoto (2003) }\end{array}$ & $\begin{array}{l}\text { An advanced manufacturing model to realize the sustainable development of } \\
\text { industries }\end{array}$ \\
\hline Sangwan (2006) & $\begin{array}{l}\text { The intersection of product development and manufacturing practices with } \\
\text { environmental issues and concerns }\end{array}$ \\
\hline $\begin{array}{l}\text { Chien and Shih } \\
(2007)\end{array}$ & $\begin{array}{l}\text { A manufacturing mode designed to minimize the environmental impact in the } \\
\text { manufacturing processes of products }\end{array}$ \\
\hline $\begin{array}{l}\text { Zhang and Wang } \\
(2005)\end{array}$ & The application of sustainable science to the manufacturing industry \\
\hline $\begin{array}{l}\text { Liu, Chen, Kang, } \\
\text { Ngai \& Li (2005) }\end{array}$ & $\begin{array}{l}\text { A modern manufacturing mode considering both the environmental impact and } \\
\text { the resource consumption during the whole product life cycle, from design, } \\
\text { fabrication, packaging, transportation, usage, recycling, to waste disposal, and its } \\
\text { objective is to minimise the negative environmental impacts and maximise the } \\
\text { utilization rate of resource, and harmonize optimization of economic benefit and } \\
\text { social benefit with the maximum integrated benefit }\end{array}$ \\
\hline $\begin{array}{l}\text { Liu, Yin, Cao \& Yan } \\
(2005)\end{array}$ & $\begin{array}{l}\text { The embodiment of the sustainable development strategy and the cycle economy } \\
\text { mode in modern manufacturing }\end{array}$ \\
\hline Polcari (2007) & $\begin{array}{l}\text { Making a comprehensive commitment to environmentally benign practices across } \\
\text { the spectrum of the manufacturing process }\end{array}$ \\
\hline Sutor (2007) & $\begin{array}{l}\text { Reducing or eliminating any negative impact on the environment by a company's } \\
\text { facilities }\end{array}$ \\
\hline $\begin{array}{l}\text { Industrial Engineer } \\
\text { (2007) }\end{array}$ & $\begin{array}{l}\text { The design and commercialization of processes and products that are feasible and } \\
\text { economical while minimizing pollution generation at the source and risk to human } \\
\text { health and the environment }\end{array}$ \\
\hline $\begin{array}{l}\text { He, Liu, Cao \& } \\
\text { Zhang (2005) } \\
\text { Glavič and Lukman } \\
\text { (2007) }\end{array}$ & $\begin{array}{l}\text { A modern manufacturing mode that takes into consideration resource } \\
\text { consumption and the environmental impact } \\
\text { Sustainable production is creating goods by using processes and systems that are } \\
\text { non-polluting, that conserve energy and natural resources in economically viable, } \\
\text { safe and healthy ways for employees, communities, and consumers and which are } \\
\text { socially and creatively rewarding for all stakeholders for the short- and long-term } \\
\text { future }\end{array}$ \\
\hline
\end{tabular}

Table 1. Definitions of green production

The term, green, is often interchanged with "sustainable" (Chien \& Shih, 2007; He et al., 2005; Industrial Engineer, 2007; Liu, Chen et al., 2005; Liu, Yin et al., 2005; Melnyk \& Smith, 1996; Polcari, 2007; Sangwan, 2006; Shiino, 1999; Sutor, 2007; Yang et al., 2003; Zhang \& Wang, 2005). The downside of such a large range of terms can hinder progress possible in academia and industry (Abdul Rashid, Evans \& Longhurst, 2008). The research literature provides a tight definition for the concept of sustainability, which in principle is concerned with meeting "the needs of the present without compromising the ability of future generations to meet their own needs" (World Commission on Environment and Development, 1987, p. 43).

In short, sustainability calls for production enterprises to make a commitment to the future and assume comprehensive responsibility for the footprint they leave behind (de Burgos \& Cespedes, 2001; Hart, 1995, 1997; Seuring, 2004; Stead \& Stead, 2000). From a practical point of view, the sustainability vision is popularly associated with the Triple Bottom Line (3BL) framework, which entails measuring organisational and societal success through the three Ps of people, planet and profit 
(Elkington, 1997; Jovane et al., 2008; Kleindorfer et al., 2005; Lovins, Lovins \& Hawken, 1999; Saha \& Darnton, 2005). This translates into the triple goal of maintaining viable social franchises (the wealth of employees, customers, and communities), as well as viable environmental franchises (the respect of the carrying capacity of ecosystems), as well as viable economic franchises (the obtainment of competitive returns on the capital assets and other inputs used to produce outputs) (Dobers \& Wolff, 2000; Hart, 1997; Rahimifard \& Clegg, 2007; Seliger, Kim et al., 2008; Stead \& Stead, 2000).

Taking a more clinical production perspective, the definitions of green given in the literature are generally linked to the aim of making business practices compatible with the nature's demands (table 1). Only Yang et al. (2003), Liu, Yin et al. (2005), Liu, Chen et al. (2005) adopt a tighter link with sustainability, and strive to make more explicit the linkage with social and economic issues. Japan deserves particularly to be mentioned for work on industrial ecology. In the late 1960s, took serious steps to orient the development of the Japanese economy toward activities that would be less dependent on the consumption of materials, and based more on information and knowledge (Erkman, 1997).

The benefit of such a linkage is that it draws into the debate a much wider body of literature and existing knowledge. The use of the term green production rather than sustainable manufacture emphasises operational processes economic effectiveness within industry and their inter-relationship with the society. Green production is implicitly linked to product design as innovations in product and process transform the overall manufacturing system. Therefore, we offer our own definition of green production that is both an amalgam of the popular definitions, yet also reflects this linkage, namely:

Finding 1: Green production is the application of environmentally and socially sensitive practices to reduce the negative impact of manufacturing activities while, at the same time, harmonising the pursuit of economic benefits.

\subsection{Evolution of research on green production}

It is difficult to clinically plot an evolution in the usage of the term "green production" in the scientific press. The term "green" was used for the first time in 1971, when the radical environmental group Greenpeace was founded (Kurtz, 2007). Within this group, the meaning of green was defined as taking actions to change attitudes and behaviours, to conserve the environment and promote peace. Although early concerns about ecological issues have been shown by authors 
already in the 1960s, convincing literature about green production has been published starting from the 1970s, when the green front began to coalesce and affect political thought (Saha \& Darnton, 2005).

The first publication in the area is probably a report commissioned by the Club of Rome (a global organisations campaigning on political issues) and entitled "Limits to growth" (Meadows, Meadows, Randers \& Behrens, 1972). Written in 1972, this report models the dramatic consequences of rapidly growing world population and finite resource supplies. Since then, green production has received important attention in the literature, the last couple of decades showing a real outbreak of the number of publications on the topic (de Burgos \& Cespedes, 2001; Stead \& Stead, 2000). This body of research clearly plots an evolution of the scope and the focus of the green production view (figure 1 ).

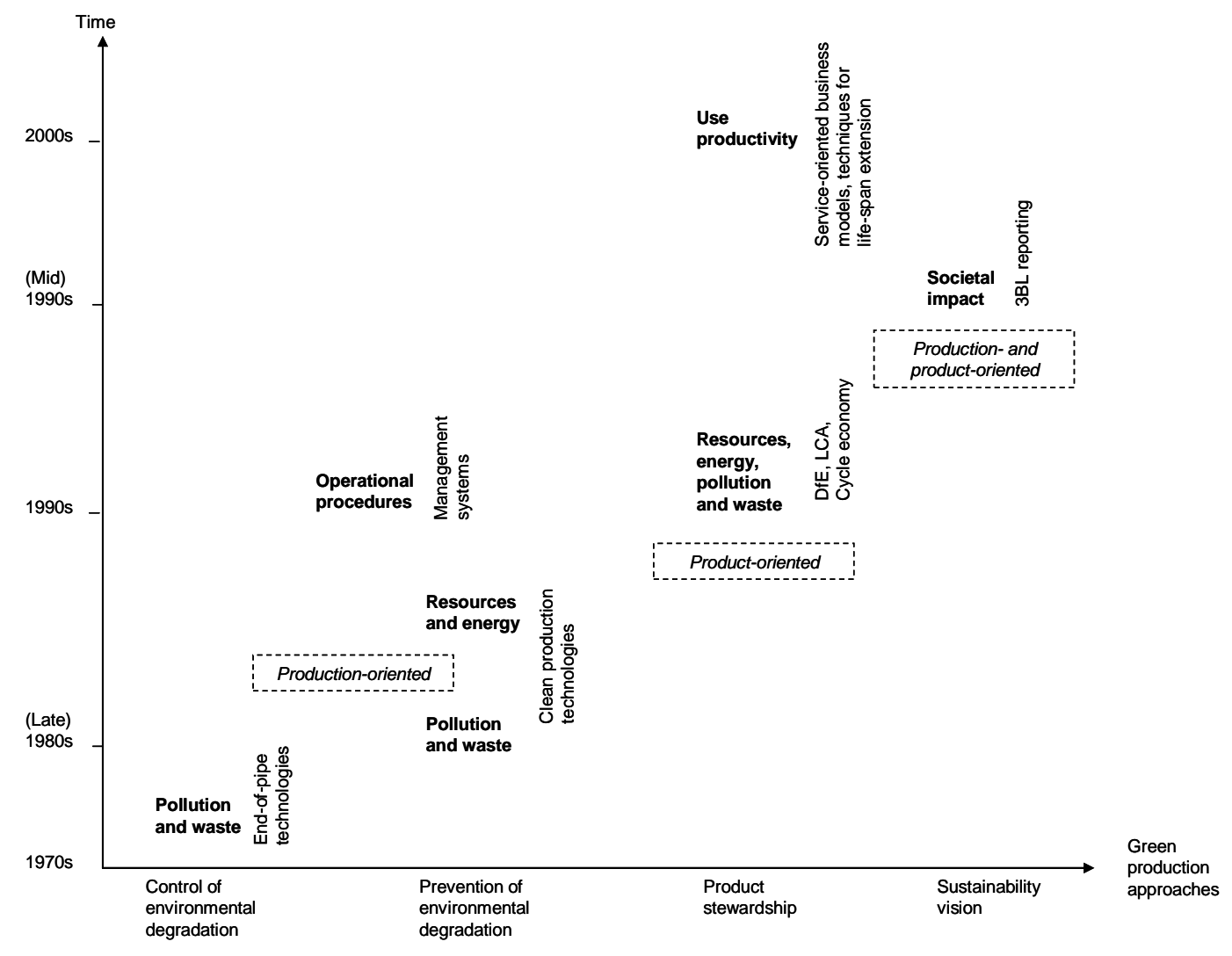

Figure 1. Evolution of the green production view

The traditional way of looking at green production was, indeed, to focus on pollution prevention and pollution control technologies. Pollution control has been adopted since the 1970 s and is based on the use of "end-of-pipe" solutions to ensure a proper disposal of waste and reduce the release of pollutants after they have been 
generated (e.g. external recycling, treatment, recovery) (Dills \& Stone 2007; Hart, 1997; Rusinko, 2007; Sangwan, 2006; Sarkis \& Cordeiro, 2001; Vachon, 2007).

The emphasis moved to pollution prevention approaches during the 1980s (Hart, 1995). Also known as "clean technologies", these are more proactive as they aim to eliminate pollution and waste and the source and, in addition, make efficient use of energy and materials (e.g. process and equipment modification, facilities retrofitting, material substitution, modularisation) (Chiang \& Tseng, 2005; Mohanty \& Deshmukh, 1998; Porter \& van der Linde, 1995; Rusinko, 2007; Sangwan, 2006; Sarkis \& Cordeiro, 2001; Seliger \& Zettl, 2008; Vachon, 2007). Here, although bigger investments are required, increased benefits can be achieved in the long term (Hart, 1995; Preuss, 2001; Sarkis \& Cordeiro, 2001).

The distinction between pollution prevention and pollution control then blurred during the 1990s, when aspects of both pollution control and pollution prevention were then re-integrated (Vachon, 2007). In practice, this included efforts to evaluate the environmental impact during investment decisions (as required for environmental certifications, e.g. ISO 14001 or EMAS), as well as operating procedures which limit or reduce the negative impact of production processes on the natural environment (e.g. inventory management, production scheduling, employee training) (Hart, 1997; Kleindorfer et al., 2005; Saha \& Darnton, 2005; Tibert, 2008).

During the 1990s the practice of product stewardship was introduced and entailed a deeper and more inclusive approach to green management. Here, the environmental perspective is extended beyond manufacturing and operations, and includes minimising the environmental burden associated with every aspect the product's lifecycle, from design, to manufacture and use, right through recycling (Hart, 1997; Richards, 1994; Rusinko, 2007; Seliger, Kim et al., 2008; Seuring, 2004). This includes adoption of techniques such as Design For the Environment (DFE) (Hart, 1995, 1997; Stead \& Stead, 2000), Life-Cycle Assessment (LCA) (Hart, 1995; Lee, 2008; Srivastava, 2007), Green Supply Chain Management (GrSCM) (Hart, 1995; Corbett \& Klassen, 2006; Lee \& Klassen, 2008; Srivastava, 2007; Beamon, 2008).

In a more generalised view, industrial ecology (Ayres \& Ayres, 2002; Frosch \& Gallopoulos, 1989; Graedel, 1994) separates the ecosphere (associated with the natural environment) and the technosphere (associated with the industrial cycle) and argues for the minimisation of waste moving from technosphere to ecosphere. In addition, recent years have seen the product stewardship perspective to also 
incorporate strategies for enhancing the productivity of the use phase, such as service-oriented business models (i.e. selling product functionalities instead of products (Baines et al., 2007; Mont, 2000) or techniques for extending the life span (e.g. preventive maintenance, realisation of multiple use phases (Seliger, Kim et al., 2008).

Similarly, during the mid-1990s an increasing number of production companies have embraced the sustainability agenda (Kleindorfer et al., 2005; Saha \& Darnton, 2005; Stead \& Stead, 2000). As mentioned before, sustainability includes considering an extended set of stakeholders, including the environment, as well as the global community and future generations. Hart $(1995,1997)$ before others (Stead \& Stead, 2000) has recognised that both pollution prevention and product stewardship practices can be used to support the sustainability vision, yet they have to be consciously directed towards improving competitiveness of delivering environmental performance (Rusinko, 2007). Various standards have evolved to reinforce this linkage; ISO 9001 emphasises quality improvements to reduce waste, ISO 14000 deals specifically with environmental management, and OHSAS18000 promotes healthier, safer and so more environmentally friendly working environments.

Overall, we have summaries this progression of "green production" as follows:

Finding 2: Intensive research on green production was initiated during the 1970s, largely with a focus on avoiding unresponsive dispersion of pollutants and wastes, evolving to emphasise clean production processes during the 1980s, then subsequently into a broader concept incorporating product stewardship and sustainability in the 1990 s and most recently post 2000 into use productivity.

\subsection{Forms of green production}

Green production has a broad definition (section 3.1) and so there are many credentials that businesses offer to support their claim to be a green producer. Implementation of each is potentially a value intensive proposition (Richards, 1994). For example, business may use environmentally friendly production technologies (Hart, 1997; Chiang \& Tseng, 2005), procurement policies (Azzone \& Noci, 1998a; Corbett \& Klassen, 2006; Green, Morton \& New, 1996), transport (Lee, 2008), packaging (Azzone \& Noci, 1998a; Richards, 1994), improve resource use (Seliger \& Zettl, 2008), etc. This is again a complex picture, but some rationalisation is possible by reflecting the concept of Eco-design (Hart, 1995; Karlsson \& Luttropp, 2006; Rahimifard \& Clegg, 2007; Richards, 1994; Stead \& 
Stead, 2000) which entails green products to be made from less and greener materials, produced by greener operations and process, delivering greener outcomes, and being greener to dispose of at the end of their life (table 2).

\begin{tabular}{|l|l|l|}
\hline \multicolumn{1}{|c|}{ Green policies } & \multicolumn{1}{|c|}{ Description } & \multicolumn{1}{c|}{ Examples } \\
\hline Green products & $\begin{array}{l}\text { Reducing the negative impact of the } \\
\text { materials included in the product and } \\
\text { its packaging }\end{array}$ & $\begin{array}{l}\text { Procter and Gamble's detergents, } \\
\text { Nike's removal of toxic chemicals from } \\
\text { shoes, } \\
\text { H\&M's Organic cotton collection, } \\
\text { McDonald's hamburger packaging }\end{array}$ \\
\hline Green processes & $\begin{array}{l}\text { Reducing the negative impact of the } \\
\text { transformation of raw materials into } \\
\text { finished goods }\end{array}$ & $\begin{array}{l}\text { Dow Chemical's products, } \\
\text { Du Pont's Pioneer seeds, } \\
\text { Stairbucks' campaign for fair-trade } \\
\text { coffee, } \\
\text { Global Social Compliance Programme }\end{array}$ \\
\hline Green use & $\begin{array}{l}\text { Reducing the negative impact } \\
\text { associated to the use phase }\end{array}$ & $\begin{array}{l}\text { Hybrid and low-emissions cars, } \\
\text { Energy efficient light bulbs, } \\
\text { Energy saving computers }\end{array}$ \\
\hline $\begin{array}{l}\text { Green end-of-life } \\
\text { management }\end{array}$ & $\begin{array}{l}\text { Enabling reuse or recycle of products } \\
\text { an the end of the useful life }\end{array}$ & $\begin{array}{l}\text { Easy-to-dissamble appliances, } \\
\text { BMW's cars, } \\
\text { Xerox's Asset Recycle Management }\end{array}$ \\
\hline
\end{tabular}

Table 2. Forms of green production

\section{Green products}

This credential concerns reducing the harmful effects of the materials included in the product or its packaging, for example avoiding use of toxic materials, minimising use of non-renewable materials, and using renewable ones according to their rate of replenishment. Cases in this policy can be Procter and Gamble's detergents which do not contain phosphates and solvents anymore (Hart, 1995), the H\&M's organic cotton clothes collection, or the paper wrappers that have replaced plastic hamburger boxes at McDonald's (Ginsberg \& Bloom, 2004; Kleiner, 1991).

\section{Green processes and operations}

Work on green processes includes machine that reduce air emissions, minimising solid and liquid wastes, saving water and energy, and protecting health and safety of production workers, customers and the local community (Richards, 1994; Ball, Evans, Levers \& Ellison, 2009). Examples can be the Dow Chemical's products, whose production processes now use reduced quantities of caustic soda and entail the treatment of a portion of the waste stream for reuse in other processes (Porter \& van der Linde, 1995), the internal and external re-use of smelter waste (Yuan \& Shi, 2009), the Daewoo Heavy Industries reduction of paint consumption and VOC emission in a vehicle painting process (Kim, Park, Hwang \& Park, 2010), the Du Pont's Pioneer seeds that provide with higher yields while also requiring less use of pesticides, or ethical trade initiatives such as the Global Social Compliance 
Programme (GSCP) which makes several major corporations, including Tesco, WalMart, IKEA and Hasbro, committed with ensuring fair labour conditions in their production sites worldwide. Kleindorfer et al. (2005) take a particularly broad view here and see this as including work on corporate image and profitability, linkages between environmental management systems, practices and operational performance, regulatory compliance, liability and negligence. Energy is an increasingly important area with many cases found, including cement (Kabir \& Madugu, 2010), chemicals (Wernet, Conradt, Isenring, Jimenez-Gonzalez \& Hungerbuhler, 2010), steel (Van Caneghem, Block, Cramm, Mortier, \& Vandecasteele, 2010) and general manufacturing (Mukherjee, 2010).

\section{Green use}

This is concerned with minimising emissions, waste and energy consumption associated with the product in use (Seliger, Kim et al., 2008). This is usually achieved by changing the design of the product and implementing innovative technologies, as in the case of low-emission diesel vehicles or of the hybrid petrolelectric cars released by Toyota, Nissan and Lexus (Dills \& Stone, 2007; Jovane et al., 2008). Common examples include also energy efficient light bulbs filled with mercury vapours (Richards, 1994) as well as the new generation of energy saving computers (Standage, 2008).

\section{Green end-of-life management}

Companies are increasingly expected, or legally required, to take responsibility for the entire life of their products, including proper recycling and disposal (Corbett \& Klassen, 2006; Gupta, 1995; Lisney et al., 2003; Seuring, 2004). Reverse supply chains include used-product acquisition, reverse logistics (moving end-of life products to reprocessing facilities), inspection and disposition (determining whether to repair, remanufacture, use of spare parts, or recycle), remanufacturing and recycling (Corbett \& Klassen, 2006; Kleindorfer et al., 2005; van Hillegersberg, Zuidwijk, van Nunen \& van Eijk, 2001). Therefore, waste management strategies increasingly involve delivery of products that can be easily reused and recycled at the end of the useful life (Rahimifard \& Clegg, 2007). For example, most appliance producers have modified their products to reduce the disassembly time (Porter \& van der Linde, 1995). BMW is extensively incorporating parts and components made of recyclable synthetics into its vehicles (Hart, 1995; Gupta, 1995), whereas Xerox, through its Asset Recycle Management Programme (ARMP), has developed a sophisticated remanufacturing process which allows to recondition parts of leased copiers and to assemble them into new machines (Hart, 1995, 1997; Reinhardt, 
1999). Similarly, take back of used machines is common to several manufacturers of electronic products, such as Canon, Kodak, IBM, HP (Reinhardt, 1999).

\section{Green supply-chain management}

(GSCM) is gaining increasing interest among researchers and practitioners of operations and supply chain management. Growing importance is driven mainly by the escalating deterioration of the environment, e.g. diminishing raw material resources, overflowing waste sites and increasing levels of pollution. The scope of GSCM ranges from reactive monitoring of the general environment management programmes to more proactive practices implemented through Rs (Reduce, Re-use, Rework, Refurbish, Reclaim, Recycle, Remanufacture, Reverse logistics, etc.) Srivastava (2007).

Collectively, this clustering of existing research helps to both, illustrate how companies present their green credentials, and appreciate where previous work has focused. Overall, this situation can be summarised as:

Finding 3: Green production credentials are claimed by: products from greener materials, produced by greener operations and process, delivering greener outcomes, and being greener to dispose of at the end of their life.

\subsection{Examples of successful green production in practice}

There are many companies that purport to have incorporated green issues into their business practices. Again, the relatively open definition of green means that it is difficult to reliably identify the better examples.

Rankings are now available that list such companies and reflect their relative performance. These include the "Dow Jones Sustainability Group Indexes" (Dow Jones Indexes, 2011) which aims at enabling a more transparent assessment of sustainability driven companies on the financial market (Dobers \& Wolff, 2000), "The global 100 most sustainable corporations" project (Global 100, 2011), which each year releases the list of the top 100 corporations in the world based on specialist evaluation of achievements on social, environmental, and strategic governance issues, the "Global Reporting Initiative" (GRI, 2011), which develops and disseminates globally applicable guidelines for sustainability reporting, and the "Climate Counts Company Scorecard" (Climate Counts, 2011), which uses 22 criteria to determine companies" individual contribution to stop climate change. Similarly, green organisations and a range of publications, including "The Sunday 
Times", "Business Week", and "The Independent" in the UK, all propose their own lists of top green companies.

\begin{tabular}{|c|c|c|c|}
\hline Organisation & Sector & Description & Link \\
\hline $3 M$ & $\begin{array}{l}\text { Technology } \\
\text { products for } \\
\text { various } \\
\text { applications }\end{array}$ & $\begin{array}{l}\text { Sustainability policies and practices directly } \\
\text { linked to the fundamental corporate values }\end{array}$ & www. 3m.com \\
\hline BMW & Automobiles & $\begin{array}{l}\text { Sustainable business management as part of } \\
\text { corporate philosophy. Member of the "Dow } \\
\text { Jones Sustainability Group Index" }\end{array}$ & www.bmwgroup.com \\
\hline Du Pont & $\begin{array}{l}\text { Science products } \\
\text { for the } \\
\text { agriculture, } \\
\text { construction, } \\
\text { transportation } \\
\text { and } \\
\text { communication } \\
\text { sectors }\end{array}$ & $\begin{array}{l}\text { Safety and environmental protection goals } \\
\text { integrated into the total value proposition and } \\
\text { the business model. Support to programs and } \\
\text { non-profit organisations that address social } \\
\text { progress of the communities in which it operates }\end{array}$ & www.dupont.com \\
\hline Ecover & $\begin{array}{l}\text { Ecological } \\
\text { detergents and } \\
\text { cleansing } \\
\text { products }\end{array}$ & $\begin{array}{l}\text { Environmental policy central to its products and } \\
\text { all company departments }\end{array}$ & www.ecover.com \\
\hline IBM & $\begin{array}{l}\text { Computer } \\
\text { technology }\end{array}$ & $\begin{array}{l}\text { Commitment to environmental leadership in its } \\
\text { operations, product design and use of } \\
\text { technology. Support to communities in need } \\
\text { through targeted grants of technology and } \\
\text { project funds }\end{array}$ & $\underline{\text { www.ibm.com }}$ \\
\hline IKEA & Furniture & $\begin{array}{l}\text { Incorporation of a number of environmental } \\
\text { strategies into its product development. Ecology } \\
\text { and social responsibility initiatives at its stores }\end{array}$ & www.ikea.com \\
\hline McDonald's & Foodservice & $\begin{array}{l}\text { Governance structure for its supply chain aiming } \\
\text { at ensuring sustainable agricultural and food } \\
\text { manufacturing practices. Environmental } \\
\text { responsibility actions at its restaurants }\end{array}$ & www.mcdonalds.com \\
\hline Monsanto & $\begin{array}{l}\text { Seeds for } \\
\text { agriculture and } \\
\text { herbicides }\end{array}$ & $\begin{array}{l}\text { Use of biotechnology to produce high yield and } \\
\text { more environmentally friendly solutions than } \\
\text { tradicional agriculture. Ethical code imposed to } \\
\text { all business partners }\end{array}$ & www.monsanto.com \\
\hline Patagonia & Clothing & $\begin{array}{l}\text { Mission statement: using business to inspire and } \\
\text { implement solutions to the environmental crisis. } \\
\text { Assurance of safe, fair and humane working } \\
\text { conditions at its factories }\end{array}$ & www.patagonia.com \\
\hline Sony & $\begin{array}{l}\text { Electronic } \\
\text { products }\end{array}$ & $\begin{array}{l}\text { Wide range of initiatives, also in collaboration } \\
\text { with its stakeholders, aiming at maintaining a } \\
\text { healthy global environment for future } \\
\text { generations. Social contribution activities } \\
\text { promoting education and society development in } \\
\text { the areas where it conducts business }\end{array}$ & www.sony.net \\
\hline $\begin{array}{l}\text { The Body Shop } \\
\text { International }\end{array}$ & Cosmetic products & $\begin{array}{l}\text { Core values in avoiding animal testing, acting } \\
\text { self esteem, defending human rights, protecting } \\
\text { the planet and supporting community trade }\end{array}$ & $\begin{array}{l}\text { www.thebodyshop.co } \\
\underline{\mathrm{m}}\end{array}$ \\
\hline $\begin{array}{l}\text { The Coca-Cola } \\
\text { Company }\end{array}$ & $\begin{array}{l}\text { Beverage } \\
\text { products }\end{array}$ & $\begin{array}{l}\text { Sustainability strategy which involves the } \\
\text { company and six of its largest bottling partners }\end{array}$ & $\begin{array}{l}\text { www.thecoca- } \\
\text { colacompany.com }\end{array}$ \\
\hline $\begin{array}{l}\text { The Dow } \\
\text { Chemical }\end{array}$ & Chemical products & $\begin{array}{l}\text { Public commitment to the pursuit of global } \\
\text { solutions to environmental issues, especially } \\
\text { climate change and energy supply. Extensive } \\
\text { programmes to reduce the impact of the } \\
\text { company's operations on site communities }\end{array}$ & www.dow.com \\
\hline
\end{tabular}

Table 3. Examples of green companies

Such rankings, however, use different criteria to judge the green credentials of a business, and different methods to judge how well these are being realised in practice. For example, most leading companies have included a commitment to social concerns into their green strategies (table 3). Popular examples are Coca Cola, 3M and BMW. Working in collaboration with its largest bottling partners, Coca Cola has developed a plan for sustainability which involves its global production, marketing and distribution systems, while $3 \mathrm{M}$ and BMW are recognised as leaders in 
green management with their pre-emptive strategies that have influenced overall industry sectors (Hart, 1995, 1997; Porter \& van der Linde, 1995). In a broader form of collaboration is industrial symbiosis where industry works together to share or trade resources for overall benefit (Beers \& Biswas, 2008; Starfelt \& Yan, 2008).

When searching for the better examples of green, an important factor to consider is the extent to which a business as actively promoted itself. Green philosophies have been incorporated by companies into the corporate culture also before the concept of sustainability was coined. Examples include "The Body Shop" (Polonsky, 1994), "Patagonia" and "Ecover" (Howarth, 2007) that have traditionally presented green issues as an essential element of brand identity. Public opinion seems to be attracted by companies that, like these, have effectively communicated their green concerns.

These are through product changes, rather than a careful consideration of the actual contribution to environmental and social matters. Here, production process innovations and end-of-life recovery schemes, such as the $3 \mathrm{M}$ 's "Pollution Prevention Pays", the Dow's "Waste Reduction Always Pays" programmes (Gupta, 1995; Hart, 1995; Miles \& Covin, 2000; Mont, 2000), or the Xerox's lease and takeback solution (Hart, 1995, 1997; Richards, 1994), have received less favour, even though they have allowed the host companies to improve environmental value while, at the same time, dramatically reduce their costs. We have attempted to capture this situation in the following finding:

Finding 4: Identifying the better examples of green production is fraught with difficulty, with existing rankings providing only limited guidance and relevance, as these appear to be heavily influenced by the extent to which business self-promote promote their green credentials.

\subsection{Drivers of green production within business}

There are many ethical reasons for the adoption of green production. However, taking a more clinical business view, the motives for adopting green production principles can be grouped into three categories.

\section{Regulation compliance}

There is a growing body of environmental regulations (e.g. in Europe, ELV 2000, WEEE 2003, RoHS 2003, PPW 2004, EUP 2005, REACH 2007) and also ISO9001, ISO14000, and OHSAS18000 that are forcing companies to reduce their resource consumption, to minimise their waste, and to take responsibility for the take-back 
of products at the end of the use phase (Kleindorfer et al., 2005; van Hillegersberg et al., 2001). However, there are also other motives that currently drive companies to engage in green production. According to Williamson, Lynch-Wood \& Ramsay (2006), these can be classified into "business case" and "business performance" motives.

\section{Market value}

The opportunity for companies to use green performance to enhance their reputation and strengthen their position in the marketplace constitutes the business case for green production. Financial institutions increasingly price companies according to their social and environmental liabilities, thus leading investors to take into consideration corporate green reputation during their acquisition decisions (Dobers \& Wolff, 2000; Fairchild, 2008). In a similar way, potential strategic partners, such as government agencies, suppliers, banks and other lenders, currently appear much more sensitive to social and environmental performance when selecting companies to create alliances (Miles \& Covin, 2000). Indeed, in some business sectors, companies are claimed to be also spurred by competitors" green activism (Polonsky, 1994). Moreover, constantly growing pressures are being exerted by non-governmental organisations, such as Green Alliance in the UK or the Coalition for Environmentally Responsible Economies (CERES) in the US, which call for a central role of the environment in public policy and business practices (Azzone \& Noci, 1998b; Miles \& Covin, 2000; Stead \& Stead, 2000).

\section{Production costs}

Business performance motives are mainly related to environmental protection actions and generally understood as opportunities for cost savings and efficiency. Porter and van der Linde (1995) provide several examples of how environment focused innovations can help companies use a range of inputs more productively. Such innovations include process enhancements, more complete material utilisation, design simplifications, elimination of unnecessary packing, recycling of scraps, improved secondary treatments, reduced handling and disposal of discharges, etc. There is substantial empirical evidence suggesting that the increase of resource productivity can offset the cost of environmental improvements, thus driving down the total cost of production (Azzone, Bertelè \& Noci, 1997; Corbett \& Klassen, 2006; Miles \& Covin, 2000; O’Brien, 1999; Preuss, 2001). In addition, adopting an eco-efficiency perspective can aid plant-level productivity efforts (Kleindorfer et al., 2005; Rusinko, 2007). Here, the view of poor resource productivity as a form of economic waste is seen to evoke Japanese management 
techniques (Hart, 1995; Porter \& van der Linde, 1995) and so to endorse the implementation of approaches such as total quality management, just-in-time, or lean production (Kleindorfer et al., 2005; Hart, 1995; de Burgos \& Cespedes, 2001; King \& Lenox, 2001). This exploration of the drivers of green production led to the following finding:

Finding 5: There appear to be three key drivers for the adoption of green production initiatives, namely, regulatory demands, market value creation and cost reduction programmes.

\subsection{Role of green production in competitive strategy}

Many businesses are keen to promote some green credentials. However, realisation of these goals does not affect companies equally; rather it depends upon the extent of their green aspirations. Here, Azzone and Noci (1998b) suggest that there are five strategic green alternatives, these being:

- Evangelist strategy: Ethical objectives and implying a radical approach to environmental issues

- Proactive green strategy: Anticipating competitive pressures and implementing systematic initiatives throughout the whole supply chain

- Responsive strategy: Largely sees the environment as a technical issue which can still be used to gain competitive advantage

- Reactive strategy: Company aims to comply with environmental regulations or customers" environmental requirements

- Unresponsive behaviour: A passive pattern of environmental behaviour and trying to delay adoption of green programmes.

Based on their work in Italy, Azzone and Noci (1998b) go on to point out that an Evangelist strategy will require more / different financial and managerial effort than a Reactive strategy. Here, environmental and ethical concerns may impact many or all company operations, ranging from the acquisition of raw materials and energy, production process, technologies and people, through to the form of the delivered product itself. For example, a company following an Evangelical strategy will avoid the use of hazardous materials, will source locally, carry out product take-back and recycling, employ environmentally friendly logistics systems, etc. The framework by 
Azzone and Noci (1998b) is thought provoking; however, the literature on strategic manufacturing suggests an alternative categorisation.

The book "Restoring our competitive edge" by Hayes and Wheelwright (1984) is amongst the most cited texts in the production operations management literature. Here, four possible roles are identified for manufacturing operations within business, namely: internally neutral, externally neutral, internally supportive, and externally supportive. The strategic value of production is progressively greater for each stage. As illustrated below, this classification can be readily translated into the concept of green production (see figure 2 ).

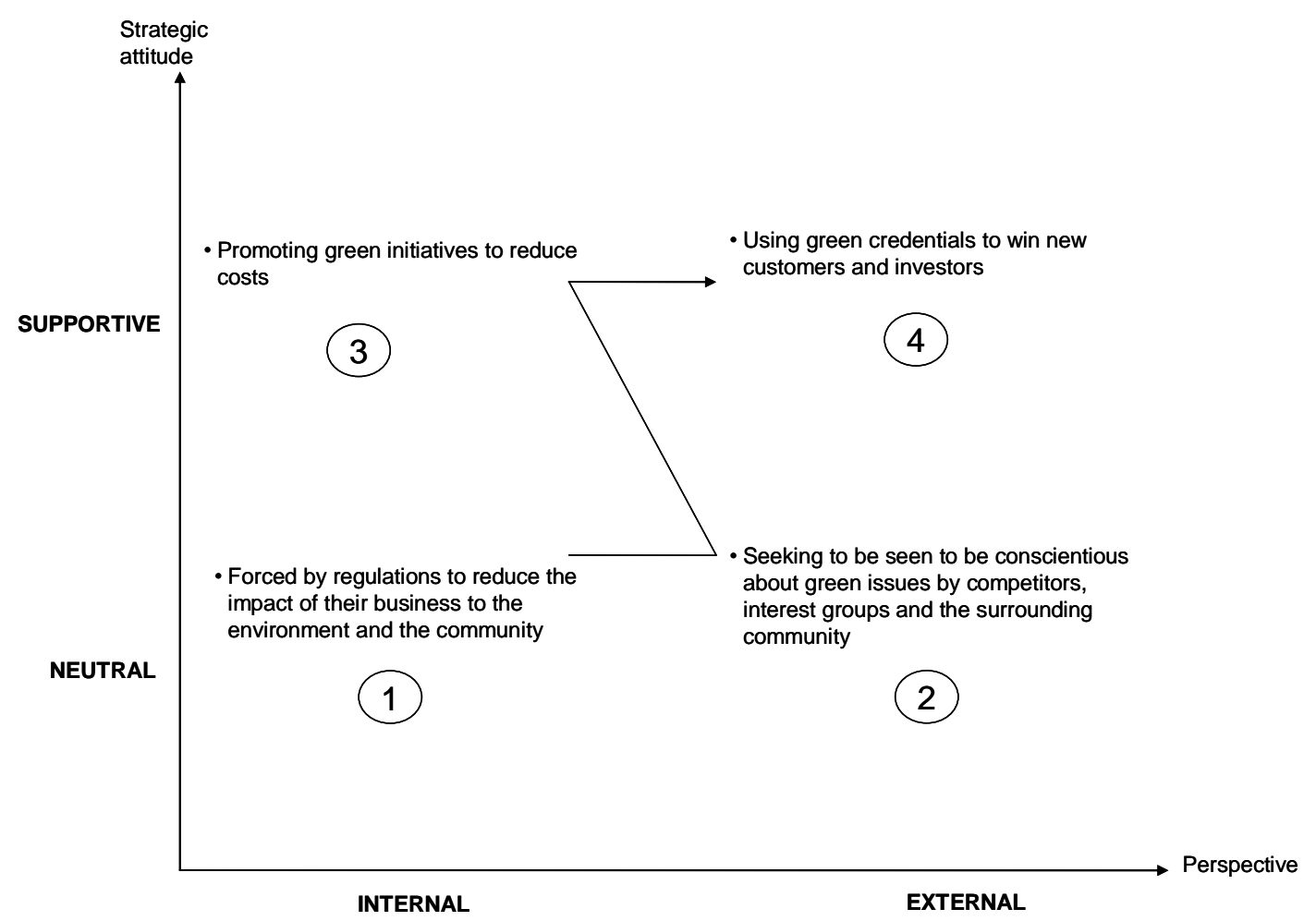

Figure 2. Roles of green production within competitive strategy

\section{Internally neutral Green production strategy}

Here, Green improvements are not expected to provide competitive advantage and, therefore, the aim of dealing with them is just to minimise potential negative impacts (e.g. taxes, fines, legal sanctions, remediation costs). As a consequence, companies at this stage approach green issues as a detrimental cost of doing business, and so they tend to restrict their actions to the minimum level required for compliance with regulations. This is the role that most studies seem to imply when they describe the application of pollution control technologies (e.g. Rusinko, 
2007), although it is not excluded that investments in state-of-the-art pollution control solutions can lead to competitive advantage (Gupta, 1995).

\section{Externally neutral Green production strategy}

The role of green issues is still regarded as neutral (at best) to competitive strategy, but neutrality is pursued against external stakeholders rather than internally to the company. Here, organisations take green improvement initiatives because they seek to align with competitors or satisfy expectations of customers, governments, investors, interest groups, and the surrounding community. This view is particularly prevalent in large corporations (Brandt, 2007, Videras \& Alberini, 2000) as they are more visible and are therefore more likely to suffer from a poor public image.

\section{Internally supportive Green production strategy}

Here, the adoption of green politics is expected to provide clear and credible support to the company's competitive strategy. In this role, green initiatives are regarded as opportunities to reduce costs and so to support cost-based competitive strategies. Such an attitude is commonly associated with the shift from pollution control to pollution prevention technologies (Hart, 1995; Polonsky, 1994; Preuss, 2001; Rusinko, 2007; Sarkis \& Cordeiro, 2001) and, although to a lesser extent, also to the introduction of product stewardship approaches (Gupta, 1995).

\section{Externally supportive Green production strategy}

With this green practices do not simply contribute to corporate strategy, they are an essential part of it. These are companies that use green policies as a tool to attract new customers and investors. In practice, these companies are proposed to compete primarily with the non-price marketing variables of reputation and product differentiation (Azzone \& Bertelè, 1994; Miles \& Covin, 2000). Indeed, numerous authors (Elsayed, 2006; Hart, 1995; Miles \& Covin, 2000; Rusinko, 2007) acknowledge the existence of an unclaimed competitive space in which companies can gain sustained early mover advantages through a reputation as green companies. Similarly, environmental and social attributes of products are claimed to have growing impact on customers" choices, to the end that companies can be allowed to also charge a premium price for them (Fairchild, 2008). This classification of green production leads to the following summary:

Finding 6: Companies have alternatives in the extent to which they underpin their competitive strategy by green production. These can be rationalised as four-five 
possible roles, ranging from a conservative adoption simply in response to regulatory pressures, through to the whole competitive strategy being pivotal on the green credentials across the design and production activities of the manufacturer.

\subsection{Challenges to implementing green production}

At the level of an individual company the challenges to implementation are affected by the green credentials sought (section 3.3), the green drivers (section 3.5) and the desired role of green production within competitive strategy (section 3.6). At a broader level, the challenges of implementing green production strategies appear to fall into three clusters, namely: internal operations, customer relationships, and corporate acceptance.

\section{Green challenges within internal operations}

Most green initiatives require radical changes in the operations area (Azzone \& Noci, 1998a; de Burgos \& Cespedes, 2001; Gupta, 1995; Mohanty \& Deshmukh, 1998). For example, a green company will avoid use of toxic materials; innovate green products and processes; improve working conditions; carry out product takeback and recycling; and so forth. These operating principles can only be delivered successfully if green performance objectives are managed jointly with more traditional operations objectives (i.e. cost, quality, delivery, flexibility) (Azzone \& Noci, 1998a; de Burgos \& Cespedes, 2001; Gupta, 1995) and a broader, more holistic view of operations management is adopted (Corbett \& Klassen, 2006). Here, complexity of operations-related decision making increases, also because of the muddy nature of the relationship between green improvement activities and associate corporate performance (Reinhardt, 1999; Rusinko, 2007). From an operations perspective, green issues must be dealt with on a continuous improvement basis and taking into account technology developments, business environment, regulations, customer demands, and society expectations (Gupta, 1995). In addition, different logics of human performance management need to be adopted in order to integrate green issues into the corporate culture and provide employees with adequate technical and management skills (Azzone, Bianchi et al., 1997; Azzone \& Noci, 1998a; Azzone \& Noci, 1998b; Ginsberg \& Bloom, 2004). One of the problems in this area is the lack of guidance for businesses to achieve more sustainable production (Nash, 2009). 


\section{Green challenges within customer relations}

The success of green policies on the market depends considerably on being sensitive to the characteristics of potential target segments (Dobers \& Wolff, 2000; Ginsberg \& Bloom, 2004; Reinhardt, 1999) since, by their nature, green customers are very diverse in terms of interests, motives, priorities, degrees of concern, etc. (Stead \& Stead, 2000). This may discourage companies from promoting their green production efforts (Polonsky, 1994), especially if their customer base is broad and geographically scattered (Ginsberg \& Bloom, 2004). Nevertheless, companies that decide to publicise their green activities have to master customers" lack of faith in green claims (Polonsky, 1994; Reinhardt, 1999), as greenwashing habits have been prevalent in the past (Azzone \& Bertelè, 1994; Ginsberg \& Bloom, 2004; Kurtz, 2007). Here, customers" misperceptions may outweigh objective measures of corporate green performance (Azzone, Bianchi et al., 1997; Polonsky, 1994). Finally, a focus on communication strategies that clearly describe the value proposition to the customers is necessary to achieve product and brand differentiation (Reinhardt, 1999; Kuk, Fokeer \& Hung, 2005).

\section{Green challenges with corporate acceptance}

Introducing the green dimension into corporate strategy sets-up particular challenges. Green values are specific and different from traditional objectives of production businesses (Azzone, Bianchi et al., 1997), and hence the decision to invest in green policies with respect to more traditional sources of differentiation and cost reduction often requires complex and conflicting trade-offs (Azzone \& Bertelè, 1994; Kuk et al., 2005); Reinhardt, 1999; Sangwan, 2006). Managers must be aware that green policies do not automatically lead to positive returns (Corbett \& Klassen, 2006; Sarkis \& Cordeiro, 2001) and treat green issues as any other business problem (Reinhardt, 1999). Here, the main dilemma is that green strategies imply a long term commitment, as they are very unlikely to generate substantial profits in the short run (Hart, 1995; Sarkis \& Cordeiro, 2001). Risk also needs to be considered that the company lacks the capabilities to realise the changes and new developments necessary to strategise green improvements (Kuk et al., 2005) or, likewise, is not able to protect itself from imitators and competitors for long enough to reap financial profit (Reinhardt, 1999). Finally, an open, optimistic, and forward looking strategic mindset is needed within organisations to overcome the view of green issues as only political or moral responsibilities (Reinhardt, 1999) and cultivate the idea that it makes business sense to integrate green thinking into corporate decision making. 
Finding 7: There are three key challenges to implementing green production, namely; changes to production technologies and hardware, acceptance by the customer base, and buy-in of stakeholders across the operations of the manufacturer.

\section{Discussion and concluding remarks}

There is little doubt that green strategies offer significant strategic opportunity for manufacturers. An increasing awareness of sustainability issues can increase consumer demand for products (Kleindorfer et al., 2005), and more and more stakeholders are asking or requiring organisations to be more environmentally responsible and eco-efficient with respect to their products or processes (Dangayach \& Deshmukh, 2001; Rusinko, 2007). As society becomes increasingly concerned with environmental issues, those companies with more adventurous green strategies are likely to:

- Be leaders in the development of new products and businesses opportunities

- Have excellent growth potential

- Seek to maintain production operations locally

- Positively contribute to addressing environmental issues

There is also little doubt that expertise in production operations will be just as essential to the future success of manufacturers as it has been in the past. However, the knowledge set of professionals in this field will undoubtedly need to continue to evolve to embrace the concepts of green and sustainable production. This paper has set out to contribute to this process through a review of literature on green from a conventional production operations perspective. Through this process we have contributed a set of findings that capture the current state-of-the-art of this topic. In summary, that green production is commonly seen as "the application of environmentally and socially sensitive practices to reduce the negative impact of manufacturing activities while, at the same time, harmonising the pursuit of economic benefits" (Finding 1).

Research in green production has moved from waste avoidance to, most recently, use productivity (Finding 2 ). Within the field of green production, credentials are claimed in the area of product, process, use and end of life (Finding 3 ) with sparse cases on companies tending to focus on product brand rather than life cycle impact 
(Finding 4). There are a number of incentives to move to green production including regulatory pressures, market opportunities and potential cost savings (Finding 5) and as a result companies adopt different production strategies (Finding 6). In deploying such strategies many challenges exist at operational and corporate levels as well as market facing (Finding 7).

This has been a complex topic to review. The existing knowledge base is somewhat fragmented; the term, green, is used widely and loosely in the popular press; there are many ways that companies can claim credentials for green production; and there are clearly differing values placed on green production within competitive strategy. At this level, it appears that our existing knowledge of production operations is inadequate to support the rapid growth of green producers and that many firms will be slow to reap the benefits of these new business opportunities.

In contrast to many traditional manufacturers, here, factors such as the sources of materials, proximity to markets, control over production, and ethics of employment, are key to brand identity and product differentiation. Moreover, the change in values that accompanies green production also challenges conventional thinking on production operations design and management. For example, it may be an anathema to seek cost reductions by outsourcing production to low wage economies. Thus, on conclusion of their review, the authors have been led to question "what are the production centred issues that can impact the growth of based green manufacturers?" This is a relatively unexplored topic within the mainstream operations research and which could provide rich opportunities for further exploration.

\section{References}

Abdul Rashid, S. H., Evans, S., \& Longhurst, P. (2008). A comparison of four sustainable manufacturing strategies. International Journal of Sustainable Engineering, 1(3), 214-229. http://dx.doi.org/10.1080/19397030802513836

Ayres, R. U., \& Ayres, L. W. (2002). A Handbook of industrial ecology. Northampton, MA: Edward Elgar Publishing.

Azzone, G., \& Bertelè, U. (1994). Exploiting green strategies for competitive advantage. Long Range Planning, 27(6), 69-81. http://dx.doi.org/10.1016/0024$\underline{6301(94) 90165-1}$ 
Azzone, G., Bertelè, U. \& Noci, G. (1997). At last we are creating environmental strategies which work. Long Range Planning, 30(4), 562-571. http://dx.doi.org/10.1016/S0024-6301(97)00035-6

Azzone, G., Bianchi, R. Mauri, R., \& Noci, G. (1997). Defining operating environmental strategies: Programmes and plans within Italian industries. Environmental Management and Health, 8(1), 4-19. http://dx.doi.org/10.1108/09566169710159159

Azzone, G., \& Noci, G. (1998a). Seeing ecology and "green" innovations as a source of change. Journal of Organizational Change, 11(2), 94-111. http://dx.doi.org/10.1108/09534819810212106

Azzone, G., \& Noci, G. (1998b). Identifying effective PMSs for the deployment of "green" manufacturing strategies. International Journal of Operations \& Production $\quad$ Management, 308-335. http://dx.doi.org/10.1108/01443579810199711

Baines, T. S., Lightfoot, H. W., Evans, S., Neely, A., Greenough, R., Peppard, J., Roy, R., Shehab, E., Braganza, A., Tiwari, A., Alcock, J. R., Angus, J. P., Bastl, M., Cousens, A., Irving, P., Johnson, M., Kingston, J., Lockett, H., Martinez, V., Micheli, P., Tranfield, D., Walton, I. M., \& Wilson, H. (2007). State-of-the-art in product-service systems. Proc. IMechE, Part B: J. Engineering Manufacture, 21(10), 1543-1552. http://dx.doi.org/10.1243/09544054JEM858

Baines, T. S., Lightfoot, H. W., Williams, G. M., \& Greenough, R. M. (2006). Stateof-the-art in lean design engineering: A literature review on white collar lean. Proc. IMechE, Part B: Jounal of Engineering Manufacture, 220(9), 1539-1547. http://dx.doi.org/10.1243/09544054JEM613

Ball, P. D., Evans, S., Levers, A., \& Ellison, D. (2009). Zero carbon manufacturing facility-towards integrating MEW process flows. Proc. IMechE Part B: Journal of Engineering Manufacture, 223(9), 1085-1096. http://dx.doi.org/10.1243/09544054JEM1357

Beamon, B. M. (2008). Sustainability and the Future of Supply Chain Management. Operations and Supply Chain Management, 1(1), 4-18.

Beers, D. V., \& Biswas, W. K. (2008). A regional synergy approach to energy recovery: The case of the Kwinana industrial area, Western Australia. Energy Conversion and Management, 49(11), 3051-3062. http://dx.doi.org/10.1016/j.enconman.2008.06.008 
Benedettini, O., Baines, T. S., Lightfoot, H. W., \& Greenough, R. M. (2009). Stateof-the-art in integrated vehicle health management. Proc. IMechE, Part G: Journal of Aerospace Engineering, 223(2), 157-160. http://dx.doi.org/10.1243/09544100JAERO446

Brandt, D. (2007). A world gone green. Industrial Engineer, 39(9), 29-33.

Chiang, J., \& Tseng, M. (2005). The impact of environmental characteristics on manufacturing strategy under cleaner production principles guidance. The Journal of American Academy of Business, 7(1), 163-168.

Chien, M. K., \& Shih, L. H. (2007). An empirical study of the implementation of green supply chain management practices in the electrical and electronic industry and their relation to organizational performance. International Journal of Environment Science and Technology, 4(3), 383-394.

Corbett, C. J., \& Klassen, R. D. (2006). Extending the horizons: Environmental excellence as key to improving operations. Manufacturing \& Service Operations Management, 8(1), 5-22. http://dx.doi.org/10.1287/msom.1060.0095

Dangayach, G. S., \& Deshmukh, S. G. (2001). Manufacturing strategy: Literature review and some issues. International Journal of Operations \& Production Management, 21(7), 884-932. http://dx.doi.org/10.1108/01443570110393414

De Burgos Jiménez, J. \& Cespedes Lorente, J. J. (2001). Environmental performance as an operations objective. International Journal of Operations \& Production Management, 21(12), 1553-1572. http://dx.doi.org/10.1108/01443570110410900

Dills, J. \& Stone, H. (2007). Environmentally conscious technologies. Surface Mount Technology, 21(6), 14-19.

Dobers, P., \& Wolff, R. (2000). Competing with "soft" issues - from managing the environment to sustainable business strategies. Business Strategy and the Environment, 9(3), 143-150. $\quad$ http://dx.doi.org/10.1002/(SICI)10990836(200005/06)9:3<143::AID-BSE239>3.0.CO;2-C

Elkington, J. (1997). Cannibals with Forks: The Triple Bottom Line of 21st Century Business. Oxford: Capstone Publishing.

Elsayed, K. (2006). Reexamining the expected effect of available resources and firm size on firm environmental orientation: an empirical study of UK firms. 
Journal of Business Ethics, 65(3), 297-308. http://dx.doi.org/10.1007/s10551-006$6402-z$

Erkman, S. (1997). Industrial ecology: An historial view. Journal of Cleaner Production, 5(1-2), 1-10. http://dx.doi.org/10.1016/S0959-6526(97)00003-6

Esty, D. C., \& Winston, A. S. (2009). Green to gold: How smart companies use environmental strategy to innovate, create value, and build competitive advantage. Wiley, Chichester, UK.

Fairchild, R. J. (2008). The manufacturing sector's environmental motives: A gametheoretic analysis. Journal of Business Ethics, 79(3), 333-344. http://dx.doi.org/10.1007/s10551-007-9401-9

Frosch, R. A., \& Gallopoulos, N. E. (1989). Strategies for manufacturing. Scientific American, 261(3), 144-152. http://dx.doi.org/10.1038/scientificamerican0989-144

Ginsberg, J. M., \& Bloom, P. N. (2004). Choosing the right green marketing strategy. MIT Sloan Management Review, 46(1), 79-84.

Glavič, P., \& Lukman, R. (2007). Review of sustainability terms and their definitions, Journal of Cleaner Production, 15(18), 1875-1885. http://dx.doi.org/10.1016/j.jclepro.2006.12.006

Graedel, T. E. (1994). Industrial Ecology: Definition and Implementation. In R. Socolow, C. Andrews, F. Berkhout, \& et al (Eds.), Industrial Ecology and Global Change (pp. 23-41). Cambridge: Cambridge University Press. http://dx.doi.org/10.1017/CBO9780511564550.005

Green, K., Morton, B., \& New, S. (1996). Purchasing and environmental management: interactions, policies and opportunities. Business Strategy and the Environment, 5(3), 188-197. http://dx.doi.org/10.1002/(SICI)10990836(199609)5:3<188: :AID-BSE60>3.0.CO;2-P

Gupta, M. C. (1995). Environmental management and its impact on the operations function. International Journal of Operations \& Production Management, 15(8), 34-51. http://dx.doi.org/10.1108/01443579510094071

Hart, S. L. (1995). A natural-resource-based view of the firm. Academy of Management Review, 20(4), 986-1014. 
Hart, S. L. (1997). Beyond greening: Strategies for a sustainable world. Harvard Business Review, 75(1), 66-76.

Hayes, R. H., \& Wheelwright, S. C. (1984). Restoring our competitive edge: Competing through manufacturing. New York: John Wiley.

He, Y., Liu, F., Cao, H., \& Zhang, H. (2005). Process planning support system for green manufacturing and its application. Computer Integrated Manufacturing System, 11(7), 975-980.

Howarth, B. (2007). It's not easy being green. B\&T Weekly, 57(2603), 16-26.

Hui, I. K., He, L., \& Dang, C. (2002). Environmental impact assessment in an uncertain environment. International Journal of Production Research, 40(2), 375388. http://dx.doi.org/10.1080/00207540110081506

Industrial Engineer. (2007). Sustainable Universe. Industrial Engineer, 39(12), 3737.

Industry Today. (2010). A Climate of change - Manufacturing must rise to the risks and opportunities of global warming. Retrieved April 4, 2011, from www.usitoday.com/article view.asp?ArticleID $=F 272$

Jovane, F., Yoshikawa, H., Alting, L., Boër, C. R., Westkämper, E., Williams, D., Tseng, M., Seliger, G., \& Paci, A. M. (2008). The incoming global technological and industrial revolution towards competitive sustainable manufacturing. CIRP Annals - Manufacturing Technology, 57(2), 641-659.

Kabir, G., \& Madugu, A. I. (2010). Assessment of environmental impact on air quality by cement industry and mitigating measures: A case study. Environmental monitoring and assessment, 160(1-4), 91-99. http://dx.doi.org/10.1007/s10661-0080660-4

Karlsson, R., \& Luttropp, C. (2006). EcoDesign: What's happening? An overview of the subject area of EcoDesign and of the papers in this special issue. Journal of Cleaner Production, 14(15-16), 1291-1298. http://dx.doi.org/10.1016/j.jclepro.2005.11.010

Kim, J., Park, K., Hwang, Y., \& Park, I. (2010). Sustainable manufacturing: A case study of the forklift painting process. International Journal of Production Research, 48(10), 3061-3078. http://dx.doi.org/10.1080/00207540902791785 
King, A., \& Lenox, M. (2001). Lean and Green? An empirical examination of the relationship between lean production and environmental performance. Production and Operations Management, 10(3), 244-256. http://dx.doi.org/10.1111/j.19375956.2001.tb00373.x

Kleindorfer, P. R., Singhal, K., \& van Wassenhove, L. N. (2005). Sustainable operations management. Production and Operations Management, 14(4), 482492. http://dx.doi.org/10.1111/j.1937-5956.2005.tb00235.x

Kleiner, A. (1991). What does it mean to be green? Harvard Business Review, 69(4), 38-47.

Kuk, G., Fokeer, S., \& Hung. W. T. (2005). Strategic formulation and communication of corporate environmental policy statements: UK firms" perspective. Journal of Business Ethics, 58(4), 375-385. http://dx.doi.org/10.1007/s10551-004-8316-y

Kurtz, K. (2007). Global warming is hot: Branding "green" in the age of climate change. MS Thesis, California College of the Arts, San Francisco, California, USA.

Lee, C. W. (2008). Environmental regulation with green technology innovation using supply chain integration. Proceedings of the Northeast Decision Sciences Institute, Brooklyn, NY, USA, 28-30 March, 580-585.

Lee S. Y., \& Klassen, R. D. (2008). Drivers and enablers that foster environmental management capabilities in small- and medium-sized suppliers in supply chains. Production and Operations Management, 17(6), 573-586. http://dx.doi.org/10.3401/poms.1080.0063

Lisney, R., Riley, K. \& Banks, C. (2003). From waste to resource management. Management Services, 47(12), 8-14.

Liu, F., Yin, J., Cao, H., \& Yan, H. (2005). Investigations and practices on green manufacturing in machining systems. Journal of Central South University of Technology, 12(2), 18-24. http://dx.doi.org/10.1007/s11771-005-0004-2

Liu, H., Chen, W., Kang, Z. \& Ngai, T., \& Li, Y. (2005). Fuzzy multiple decision making for evaluating aggregate risk in green manufacturing. Tsinghua Science \& Technology, 10(5), 627-632. http://dx.doi.org/10.1016/S1007-0214(05)70130-9

Lovins, A. B., Lovins, L. H., \& Hawken, P. (1999). A road map for natural capitalism. Harvard Business Review, 77(3), 145-158. 
Lu, L. Y. Y., Wu, C. H., \& Kuo, T. (2007). Environmental principles applicable to green supplier evaluation by using multi-objective decision analysis. International Journal of Production Research, 45(18-19), 4317-4331. http://dx.doi.org/10.1080/00207540701472694

Meadows, D. H., Meadows, D. L., Randers, J., \& Behrens, W. W. I. (1972). The limits to growth. London: Earth Island.

Melnyk, S. A., \& Smith, R. T. (1996). Green Manufacturing, Society for Manufacturing Engineering. Dearborn, MI.

Miles, M. P., \& Covin, J. G. (2000). Environmental marketing: A source of reputational, competitive, and financial advantage. Journal of Business Ethics, 23(3), 299-311. http://dx.doi.org/10.1023/A:1006214509281

Mohanty, R. P., \& Deshmukh, S. G. (1998). Managing green productivity: Some strategic directions. Production Planning \& Control, 9(7), 624-633. http://dx.doi.org/10.1080/095372898233614

Mont, O. (2000). Product-service systems. Swedish Environmental Protection Agency, Stockholm.

Mukherjee, K. (2010). Measuring energy efficiency in the context of an emerging economy: The case of Indian manufacturing. European Journal of Operational Research, 201(3), 933-941. http://dx.doi.org/10.1016/j.ejor.2009.04.012

Nash, H. A. (2009). The European Commission's sustainable consumption and production and sustainable industrial policy action plan. Journal of Cleaner Production, 17(4), 496-498. http://dx.doi.org/10.1016/j.jclepro.2008.08.020

O'Brien, C. (1999). Sustainable production - a new paradigm for the millennium. International Journal of Production Economics, 60-61, 1-7. http://dx.doi.org/10.1016/S0925-5273(98)00126-1

Polcari, M. R. (2007). A total approach to industry sustainability. Semiconductor International, 30(1), 108-108.

Polonsky, M. J. (1994). An introduction to green marketing. Retrieved April 04, 2011, from Electronic Green Journal, 1(2), 9.

Porter, M. E., \& van der Linde, C. (1995). Green and competitive. Harvard Business Review, 73(5), 120-134. 
Preuss, L. (2001). In dirty chains? Purchasing and greener manufacturing. Journal of Business Ethics, 34(3-4), 345-359. http://dx.doi.org/10.1023/A:1012549318786

Rahimifard, S., \& Clegg, A. J. (2007). Aspects of sustainable design and manufacture. International Journal of Production Research, 45(18-19), 40134019. http://dx.doi.org/10.1080/00207540701608511

Reinhardt, F. L. (1999). Bringing the environment down to earth. Harvard Business Review, 77(4), 149-157.

Richards, D. J. (1994). Environmentally conscious manufacturing. World Class Design to Manufacture, 1(3), 15-22. http://dx.doi.org/10.1108/09642369210056601

Roarty, M. (1997). Greening business in a market economy. European Business Review, 97(5), 244-254. http://dx.doi.org/10.1108/09555349710179898

Rusinko, C. A. (2007). Green manufacturing: an evaluation of environmentally sustainable manufacturing practices and their impact on competitive outcomes. IEEE Transactions on Engineering Management, 54(3), 445-454. http://dx.doi.org/10.1109/TEM.2007.900806

Saha, M., \& Darnton, G. (2005). Green companies or green con-panies: Are companies really green, or are they pretending to be? Business and Society Review, 110(2), 117-157. http://dx.doi.org/10.1111/j.0045-3609.2005.00007.x

Sangwan, K. S. (2006). Performance value analysis for justification of green manufacturing systems. Journal of Advanced Manufacturing Systems, 5(1), 5973. http://dx.doi.org/10.1142/S0219686706000765

Sarkis, J., \& Cordeiro, J. J. (2001). An empirical evaluation of environmental efficiencies and firm performance: Pollution prevention versus end-of-pipe practice. European Journal of Operational Research, 135(1), 102-113. http://dx.doi.org/10.1016/S0377-2217(00)00306-4

Seliger, G., Kim, H., Kernbaum, S., \& Zettl, M. (2008). Approaches to sustainable manufacturing. International Journal of Sustainable Manufacturing, 1(1/2), 58-77.

Seliger, G., \& Zettl, M. (2008). Modularization as an enabler for cycle economy. CIRP Annals - Manufacturing Technology, 57,(1), 133-136. 
Seuring, S. (2004). Industrial ecology, life cycles, supply chains: Differences and interrelations. Business Strategy and the Environment, 13(5), 306-319. http://dx.doi.org/10.1002/bse.418

Shiino, J. (1999). Seventh report: Consider production system of architecture: Green manufacturing system. Architectural Product-Engineering, 401, 96-101.

Standage, T. (2008). More silicon, less carbon. Economist, 19, 108.

Starfelt, F., \& Yan, J. (2008). Case study of energy systems with gas turbine cogeneration technology for an eco-industrial park. International Journal of Energy Research, 32(12), 1128-1135. http://dx.doi.org/10.1002/er.1450

Stead, J. G., \& Stead, E. (2000). Eco-enterprise strategy: Standing for sustainability. Journal of Business Ethics, 24(4), 313-329. http://dx.doi.org/10.1023/A:1006188725928

Srivastava, S. K. (2007). Green supply-chain management: A state-of-the-art literature review. International Journal of Management Reviews, 9(1), 53-80. http://dx.doi.org/10.1111/j.1468-2370.2007.00202.x

Sutor, L. (2007). Green manufacturing comes of age. Control Engineering, 54(11), 69-72.

Tibert, L. (2008). Establishing the value of environmental policy. Industrial Management, 50(2), 17-19.

Vachon, S. (2007). Green supply chain practices and the selection of environmental technologies. International Journal of Production Research, 45(18-19), 43574379. http://dx.doi.org/10.1080/00207540701440303

Van Caneghem, J., Block, C., Cramm, P., Mortier, R., \& Vandecasteele. C. (2010). Improving eco-efficiency in the steel industry: The ArcelorMittal Gent case. Journal of Cleaner Production, 18(8), 807-814. http://dx.doi.org/10.1016/j.jclepro.2009.12.016

van Hillegersberg, J., Zuidwijk, R., van Nunen, J., \& van Eijk, D. (2001). Supporting return flows in the supply chain. Communications of the ACM, 44(6), 74-79. http://dx.doi.org/10.1145/376134.376172

Videras, J., \& Alberini, A. (2000). The appeal of voluntary environmental programs: Which firms participate and why? Contemporary Economic Policy, 18(4), 449-461. http://dx.doi.org/10.1111/j.1465-7287.2000.tb00041.x 
Wernet, G., Conradt, S., Isenring, H. P., Jimenez-Gonzalez, C., \& Hungerbuhler, K. (2010). Life cycle assessment of fine chemical production: A case study of pharmaceutical synthesis. International Journal of Life Cycle Assessment, 15(3), 294-303. http://dx.doi.org/10.1007/s11367-010-0151-z

Williamson, D., Lynch-Wood, G., \& Ramsay, J. (2006). Drivers of environmental behaviour in manufacturing SMEs and the implications for CSR. Journal of Business Ethics, 67(3), 317-330. http://dx.doi.org/10.1007/s10551-006-9187-1

World Commission on Environment and Development. (1987). Our common future. New York, NY: Oxford University Press.

Yang, C. L., Lin, S. P., Chan, Y. H., \& Sheu, C. (2010). Mediated effect of environmental management on manufacturing competitiveness: An empirical study. International Journal of Production Economics, 123, 210-220. http://dx.doi.org/10.1016/j.ijpe.2009.08.017

Yang, Y., Lu, G., Guo, X., \& Yamamoto, R. (2003). Greenness assessment of products in PLCA by DEA approach. Materials Transactions, 44(4), 645-648. http://dx.doi.org/10.2320/matertrans. 44.645

Yuan, Z. W., \& Shi, L. (2009). Improving enterprise competitive advantage with industrial symbiosis: Case study of a smeltery in China. Journal of Cleaner Production, 17(14), 1295-1302. http://dx.doi.org/10.1016/j.jclepro.2009.03.016

Zhang, H., \& Wang, X. (2005). Green manufacturing process assessment by DEA method. Acta Armamentarii, 26(4), 523-527.

The Consumer Goods Program. Retrieved April 04, 2011, from http://www.ciesnet.com/2-wwedo/2.2-programmes/2.2.gscp.background.asp.

Dow Jones Indexes. Retrieved April 04, 2011, from http://www.sustainabilityindex.com/.

Global 100. Retrieved April 04, 2011, from http://www.global100.org/.

GRI Global Reporting Initiative. Retrieved April 04, 2011, from http://www.globalreporting.org/Home.

Climate Counts. Retrieved April 04, 2011, from http://www.climatecounts.org/scorecard overview.php. 
Journal of Industrial Engineering and Management, 2012 (www.jiem.org)

(c)

SORIERIGHIS RESERVED

Article's contents are provided on a Attribution-Non Commercial 3.0 Creative commons license. Readers are allowed to copy, distribute and communicate article's contents, provided the author's and Journal of Industrial Engineering and Management's names are included. It must not be used for commercial purposes. To see the complete license contents, please visit http://creativecommons.org/licenses/by-nc/3.0/. 